\title{
KELSEN JAKO PŘEDCHŮDCE DNEŠNÍHO MEZINÁRODNĚPRÁVNÍHO KONSTITUCIONALISMU?
}

\author{
PAVEL ŠTURMA
}

\begin{abstract}
Kelsen as a Predecessor of Contemporary International Constitutionalism?
Although H. Kelsen is not named as the predecessor of constitutionalism in the international law, he inspired it in many ways. Despite several differences, there is no insuperable gap between H. Kelsen's teachings and the international constitutionalism, if we look at both of these theories not as closed models, but more as methods intended to interpret the applicable international law. One of the most inspiring parts of Kelsen's teachings is his logical approach to the legal order, which he understands as an organized body, as well as his emphasis on responsibility and sanctions. Moreover, it is important to note, that the legal rules do not directly arise from social needs, but that they are formed on the basis of a rule-making procedure, in which the role of States is the most important. It is therefore necessary to differentiate between the view (and methods) of the jurisprudence and political science or international politics. On the other hand, the international constitutionalism theory reminds us of several important fact - firstly, that all subjects, including States, are bound by the rules of international law; secondly that the role of international organizations and courts promises to grow even more; and last but not least, that the international law is not value-neutral, as its main objective is to protect peace, justice and human rights.
\end{abstract}

Keywords: theory of international law, Keslen, constitutionalism, international organizations, monism, sanction, self-defence

Klíčová slova: teorie mezinárodního práva, Kelsen, konstitucionalismus, mezinárodní organizace, monismus, sankce, sebeobrana

DOI: $10.14712 / 23366478.2017 .20$

\section{1. ÚVOD}

Téma konference „Hans Kelsen - inspirující osobnost pro právní vědu, filozofii, politiku a mezinárodní vztahy“" otevírá řadu možných přístupů. Je skutečností, že dílo Hanse Kelsena bylo a nadále zůstává inspirující nejen pro obecnou teorii a filozofii práva, popř. ústavní právo, ale také pro nauku mezinárodního práva. Při zdůrazňování př́nosu Kelsena pro jiné oblasti právní vědy by se nemělo zapomínat, že se celý život zabýval mezinárodním právem. ${ }^{1}$

1 Srov. KOSKENNIEMI, M.: The Gentle Civilizer of Nations. The Rise and Fall of International Law 1870-1960. Cambridge: Cambridge University Press, 2001, s. 240-249. 
První práce H. Kelsena z tohoto oboru spadají již do první poloviny 20. let 20. století. ${ }^{2}$ Pro právní historii stojí za připomenutí, že po krátkém působení na německé právnické fakultě Univerzity Karlovy v Praze (1936-1938) přijal Kelsen místo profesora na Institut Universitaire des Hautes Études Internationales v Ženevě (1938-1940). Tam také napsal v r. 1939 pro Československo významný posudek určený pro Společnost národů, ve které rozebral neplatnost Mnichovské dohody (1938). ${ }^{3} \mathrm{~K}$ tomuto problému se ostatně Kelsen později vrátil a označil Mnichovskou dohodu za zjevné porušení územní celistvosti a členského státu a dokonce totální zničení jeho politické nezávislosti, vyplývající z agrese nečlenského státu, které nebylo ani předmětem posouzení v rámci Společnosti národů. ${ }^{4}$ A mezinárodním právem se zabýval i po odchodu z Evropy do USA (v r. 1940) až do své smrti v Berkley (1973).

Cílem tohoto příspěvku je podívat se na známé prvky Kelsenovy teorie mezinárodního práva z nového úhlu pohledu. Smyslem ohlédnutí se za myšlenkami tohoto známého autora je totiž především otázka, zda a v čem je jeho dílo stále aktuální a inspirující pro současnou nauku mezinárodního práva. Konkrétně jde o srovnání jeho teorie s jedním ze současných teoretických směrů, jež by mělo dát odpověd’ na otázku, zda lze Kelsena považovat za „otce“ či předchůdce současného mezinárodněprávního konstitucionalismu. Tato otázka se přirozeně nabízí vzhledem k určitým podobnostem i vzhledem $\mathrm{k}$ tomu, že sám Kelsen se původně zabýval ústavním právem. To znamená, že i ve svých dílech věnovaných čistě otázkám mezinárodního práva se často projevuje jeho inspirace nejen teoretickými východisky ryzí nauky právní, ale také modely vycházející z vnitrostátního veřejného práva, především práva ústavního. Zbývá však prozkoumat, zda jde o skutečnou, nebo jen zdánlivou (falešnou) analogii.

\section{KELSEN JAKO TEORETIK MEZINÁRODNÍHO PRÁVA}

Hned první Kelsenova významná práce se týkala problému suverenity a teorie mezinárodního práva. ${ }^{5}$ Její podtitul je symptomatický. Ukazuje, že Kelsen nikdy neodděloval mezinárodní právo od obecné teorie práva, ale naopak aplikoval ryzí nauku právní (Reine Rechtslehre) i na oblast mezinárodního práva. Na tuto práci pak navázal první ze tří kursů pro Akademii mezinárodního práva v Haagu, který měl Kelsen v roce 1926.6

2 KELSEN, H.: Das Problem der Souveränität und die Theorie des Völkerrechts. Beitrag zu einer reinen Rechtslehre. Tübingen: J. C. B. Mohr, 1920.

3 Viz Kelsen's Memorandum deposited in the Archives of the Czech Army, fund J. Kopecký, Box No. 1. Srov. též KUKLÍK, J.: The Validity of the Munich Agreement and the Process of its Repudiation during the Second World War as Seen from the Czechoslovak Perspective. In SKŘIVAN, A. (ed.): Prague Papers on History of International Relations. Praha: Institute of World History II, 1998, s. 351.

4 KELSEN, H.: Peace Through Law. Chapel Hill: The University of North Carolina Press, 1944, reprint 2001, s. 52.

KELSEN, H.: Das Problem der Souveränität und die Theorie des Völkerrechts. Op. cit.

6 KELSEN, H.: Les rapports de système entre le droit interne et le droit international public. Recueil des Cours, sv. 13, č. 4/1926, s. 231. 
Je známou skutečností, že pro Kelsena byla suverenita právní koncept, nikoli právo předcházející, historicky podmíněný, politický fakt, ${ }^{7}$ což byl naopak prŕstup Kelsenova ideového protivníka Carla Schmitta.

Z hlediska ryzí nauky právní není právo funkcí, výsledkem činnosti státu, existujícího jako objektivní sociální fakt. V tomto pojetí je stát zcela identifikován se svým právním řádem (Rechtsordnung). ${ }^{8} \mathrm{~V}$ rámci mezinárodního práva ovšem stát vystupuje jako právní subjekt, ale Kelsen odmítá antropomorfní pojetí subjektivity. Naopak stát se jeví jako dílčí právní řád $\mathrm{v}$ rámci vyššího, mezinárodněprávního řádu.

V tomto smyslu není zásadního rozdílu mezi právem vnitrostátním a mezinárodním. Každý právní rád je podle Kelsena uzavřený a úplný. Stejně jako ve vnitrostátním právu i v právu mezinárodním musí být podle Kelsena základní norma (Grundnorm nebo Ursprungsnorm). Takovou základní normou v mezinárodním právu mělo být pravidlo pacta sunt servanda, ${ }^{9}$ ale v pozdějších dílech se Kelsen od této myšlenky odvrátil, protože jde jen o obyčejovou normu, která je základem, ze které odvozují svou platnost smlouvy, ale nestačí jako důvod platnosti mezinárodního obyčeje. Proto ji nahradil základní normou ve znění, že státy se mají chovat tak, jak se obvykle chovaly. ${ }^{10}$

Dalším charakteristickým znakem Kelsenovy teorie je monismus ve vztahu mezinárodního a vnitrostátního práva. Nejenže Kelsen vychází z představy jednoty právního řádu, který je hierarchicky uspořádaný. Navíc ani nevidí rozdíl v povaze předmětu vnitrostátního práva a mezinárodního práva. ${ }^{11}$ To je velmi moderní př́ístup, vezmeme-li v úvahu pozdější rozvoj odvětví mezinárodního práva, která neupravují jen vztahy mezi státy, ale také další oblasti lidské činnosti, včetně vztahů státu k jednotlivcům, zejména $\mathrm{v}$ oblasti lidských práv, mezinárodního ekonomického práva, práva $\mathrm{EU}$, atd. Ačkoli vznik a rozvoj těchto odvětví mezinárodního práva spadá až do druhé poloviny 20. století, Kelsen již ve svém kursu v Haagské akademii mezinárodního práva v r. 1932 potvrdil, že mezinárodní právo může upravovat i takové otázky, jako povinnosti státu ve vztahu ke svým občanům. ${ }^{12}$

To jsou mnohé myšlenky, které mohou být blízké dnešním teoretikům hlásícím se ke konstitucionalismu nebo konstitucionalizaci mezinárodního práva. Jak známo, Kelsen začínal jako ústavní právník a vzory a př́klady z vnitrostátního práva přenášel do své teorie mezinárodního práva. Jinak řečeno, podle Kelsena, aby mohlo mít právní povahu,

\footnotetext{
7 Viz KELSEN, H.: Les rapports de système... Op. cit., s. 253-255: „La puissance étatique n’est pas un simple fait. Simple fait, elle consisterait en une relations causale... si la puissance publique est souveraine, c'est qu'elle est la puissance suprême, celle à laquelle aucune autre n'est supérieure... Cet attribut qu'on lui reconnaît montre qu'il est impossible de voir en elle une qualité naturelle, une sorte de force physico-chimique. Car une semblable force, si elle était souveraine, ne serait pas moins qu'une prima causa, une cause première, la force la plus puissante d'où découlerait tout phénomène sans qu'elle eût elle-même de cause. Idée inconcevable.“

8 Srov. RIGAUX, F.: Hans Kelsen on International Law. European Journal of International Law, sv. 9, 1998, s. 330 .

9 Viz KELSEN, H.: Das Problem... Op. cit., s. 217, 262, 284.

10 Viz KELSEN, H.: Principles of International Law. New York: Rinehart, 1952, s. 417-418 („,The states ought to behave as they have customarily behaved.").

11 Srov. KELSEN, H.: Théorie générale du droit international public. Problèmes choisies. Recueil des Cours, Sv. 42, č. 4/1932, s. 178.

12 Ibid., s. 301-302.
} 
musí mezinárodní právo splňovat stejná kritéria, jako jsou ta, která určují právní charakter státu, resp. jeho právního řádu (což je v normativistickém pojetí totéž). ${ }^{13}$

Zde se projevují určité tradiční rysy úzkého pojetí práva vycházejícího z vnitrostátních právních řádů. Pro Kelsena je totiž donucení klíčovým znakem, který odlišuje právo od jiných normativních systémů, jako je např. morálka. Právo je pro něj donucující rád (coercive order, ordre de contrainte, Zwangsordnung). Jinak řečeno, mezinárodní právo je skutečným odvětvím práva, jen pokud disponuje svými vlastními donucovacími prostředky. Kelsen proto hledá a nalézá odpověd’ v použití síly jako sankce ve vztazích mezi státy. „Mezinárodní právo je právem ve stejném smyslu jako národní právo za předpokladu, že je možné v zásadě interpretovat použití síly namířené jedním státem proti jinému bud' jako sankci, nebo jako delikt.."14

Kelsen si ovšem uvědomuje, že mezinárodní společenství není uspořádáno jako státní řad, ale jako decentralizovaný rád, primitivní systém práva. ${ }^{15} \mathrm{~V}$ takovém systému není použití síly centralizované, ale je realizované jednotlivými členy společenství, a to ve formě svépomoci (self-help, Selbsthilfe). ${ }^{16}$ Taková svépomoc se uplatňuje podle pravidel stanovených tímto společenstvím, což je typické pro mezinárodní právo.

Jinak řečeno, válka a represálie jsou sankce (Unrechtsfolge) v mezinárodním právu, které umožňují kvalifikovat mezinárodní právo jako právní řád. ${ }^{17}$ Tato myšlenka provází Kelsena od prvních prací až po dílo napsané po 2 . světové válce a po přijetí Charty OSN. ${ }^{18}$ Třebaže již v 30 . letech řada internacionalistů odmítala teorii spravedlivé války a přiklonila se $\mathrm{k}$ jejímu zákazu, nebyl př́stup Kelsena ojedinělý. V období po roce 1945 se ale vedení války jako svépomocného donucení (sankce) dostalo do jasného rozporu s pozitivním mezinárodním právem.

Kelsenova teorie ovšem nebyla jednoduchým odmítnutím nebo ignorováním vývoje v mezinárodním právu. Jde o poměrně propracovanou a logicky zdůvodněnou koncepci, která je postavená na teorii spravedlivé války (bellum iustum). Pouze spravedlivá válka může plnit funkci sankce, kdežto nespravedlivá válka je mezinárodním deliktem.

Kelsen představil své zdůvodnění teorie spravedlivé války v práci uveřejněné v době války (r. 1942), již v americké emigraci. ${ }^{19}$ Předložil celkem pět argumentů pro její zdůvodnění. První z nich má překvapivě spíš sociologickou povahu, dokazuje, že již před vypuknutím 1 . světové války veřejné mínění neakceptovalo volnost států uchýlit se $\mathrm{k}$ válce bez spravedlivého důvodu, a vlády navíc vždy zdůvodňovaly své akce jako obranné. Druhý argument Kelsen opřel o tehdejší pozitivní právo, zejm. čl. 231 Versailleské smlouvy (1919), čl. 15 odst. 7 Paktu Společnosti národů (1919) a Briand-Kelloggův pakt (1928). Další tři argumenty se pak opírají o právo primitivních společností, doktrínu bellum iustum od Antiky až po Grotia a pojetí mezinárodního práva jako primitivního právního řádu.

13 Viz KELSEN, H.: Principles of International Law. Op. cit., s. 18.

14 Ibid., s. 18.

15 Viz KELSEN, H.: Théorie générale du droit international public. Op. cit., s. 131-132.

16 Viz KELSEN, H.: Das Problem... Op. cit., s. 258.

17 Viz KELSEN, H.: Théorie générale du droit international public. Op. cit., s. 133-134.

18 Viz KELSEN, H.: Principles of International Law. Op. cit., s. 18, 59, 401.

19 KELSEN, H.: Law and Peace in International Relations. The Oliver Wendell Holmes Lectures. Cambridge: Harvard University Press, 1942, s. 36-55. 
Kelsen se k tomu vrátil v další knize „Mír prostřednictvím práva“ z r. 1944. ${ }^{20}$ Některé z těchto myšlenek se objevují i v pozdějších pracích H. Kelsena, ve kterých již reagoval systém kolektivní bezpečnosti založený Chartou OSN, at’ již jde o jeho článek o kolektivní bezpečnosti a kolektivní sebeobraně z r. 1948, ${ }^{21}$ nebo o knihu věnovanou Chartě OSN. 22

Někteří dnešní autoři se vracejí ke Kelsenově knize z r. 1944, napsané ještě před založením OSN. Jeho návrh na vytvoření „stále ligy pro udržení míru“ (Permanent League for the Maintenance of Peace) je oprávněně srovnáván s Kantovým spisem $K$ věčnému míru. ${ }^{23}$ Práce byla čtena a komentována jeho současníky. Někteří souhlasili $\mathrm{s}$ jeho myšlenkou na centralizaci soudního řešení mezinárodních sporů. ${ }^{24}$ Jiní ovšem poukazovali na to, že i když by bylo možné uplatnit mezinárodní soudnictví na všechny spory, samo o sobě to není zárukou míru. Také upozorňovali na význam jiných, mimosoudních či politických prostředků řešení sporů. ${ }^{25}$

Podle Kelsena existuje rozdíl mezi obecným mezinárodním právem, kde převládá zásada svépomoci, včetně decentralizovaného, individuálního donucení, jež je v rukou jednotlivých států, a systémem kolektivní bezpečnosti podle Charty OSN. V prrípadě kolektivní bezpečnosti je použití síly centralizované, na základě rozhodnutí ústředního orgánu společenství. ${ }^{26}$ Centralizace použití síly (at’ již v rámci státu nebo mezinárodní organizace) je však možná pouze s významným omezením. Tato výjimka se týká př́ípadu sebeobrany. Jak vysvětluje Kelsen ve svém článku, sebeobrana není totožná se svépomocí. Jedná se o zvláštní př́ípad svépomoci proti specifickému porušení práva, a to protiprávnímu použití síly, nikoli proti jiným porušením. Sebeobrana je to minimum svépomoci, které musí být dovolené dokonce i v systému kolektivní bezpečnosti, založeném na monopolu společenství na centralizované použití síly. ${ }^{27}$

Kelsen dále připomíná, že v systému kolektivní bezpečnosti organizovaném na úplné centralizaci legitimního použití síly je sebeobrana jen výjimečnou a dočasnou mezihrou mezi aktem agrese a kolektivní donucovací akcí, kterou podnikne společenství jako sankci proti protiprávnímu použití síly. Zcela odlišný př́ípad je tehdy, když se sebeobrana uplatní, protože kolektivní bezpečnost z nějakého důvodu nefunguje. Pak sebeobrana není výjimečným a dočasným opatřením přijatým v rámci fungujícího

20 KELSEN, H.: Peace Through Law. Op. cit.

21 KELSEN, H.: Collective Security and Collective Self-Defense under the Charter of the United Nations. The American Journal of International Law, sv. 42, č. 4/1948, s. 783.

22 KELSEN, H.: The Law of the United Nations. A Critical Analysis of Its Fundamental Problems. London: Stevens \& Sons, 1952.

23 Srov. ZOLO, D.: Hans KELSEN: International Peace through International Law. European Journal of International Law, sv. 9, 1998, s. 317; SCHMÄDEL, J. von: Kelsen's Peace through Law and its Reception by his Contemporaries. Hitotsubashi Journal of Law and Politics, sv. 39, 2011, s. 76.

24 Viz KUNZ, J. L.: Compulsory International Adjudication and Maintenance of Peace. The American Journal of International Law, sv. 38, č. 4/1944, s. 678; POTTER, P. B.: Review, The American Journal of International Law, sv. 39, č. 1/1945, s. 137 an.

25 Srov. KUNZ, J. L.: Op. cit., s. 677; MORGENTHAU, H.: The Machiavellian Utopia. Ethics, sv. 55, č. 2/1945, s. 146; NIEMEYER, G.: Review. Harvard Law Review, sv. 58, č. 2/1944, s. 306.

26 KELSEN, H.: Collective Security and Collective Self-Defense. Op. cit., s. 783-784.

27 Ibid., s. 784. 
systému kolektivní sebeobrany, nahrazením tohoto zablokovaného systému opačným principem svépomoci. ${ }^{28}$

Je pozoruhodné, jak Kelsen již v r. 1948 prozíravě odhadl a přesně analyzoval problémy, se kterými se bude potýkat systém kolektivní bezpečnosti OSN, založený na principu jednomyslnosti (veto) stálých členů Rady bezpečnosti. Došel k tomu na základě rozboru př́íslušných ustanovení Charty OSN, nebot' v té době ještě neexistovala významnější praxe Rady bezpečnosti. Současně porovnal tento systém podle Charty OSN s Paktem Společnosti národů. Pakt ještě nestanovil pro členy Společnosti národů povinnost zdržet se hrozby silou a zdržet se za všech okolností použití síly. Členové se pouze nesměli uchýlit $\mathrm{k}$ válce proti státu, který se ve sporu předloženém Radě podřídil jejím doporučením. Pakt nezaložil monopol společenství na centralizované použití síly, proto se princip svépomoci do značné míry udržel. Kelsen proto logicky dospívá k závěru, že systém Společnosti národů byl mnohem méně efektivní než systém zřízený Chartou, ovšem za předpokladu, jak dodává, že tento nový systém může vůbec fungovat. ${ }^{29}$

Jinak řečeno, ač teoreticky považuje systém podle Charty OSN za dokonalejší, Kelsen neskrývá své pochybnosti. Podle Kelsena je otevřený rozpor mezi ideologií Organizace spojených národů a její právní ústavou. ${ }^{30}$ Především vidí určité nedostatky v samotné Chartě. Podle jeho pojetí, když je kolektivní bezpečnost založena na centralizaci donucovacích opatření v rukou Rady bezpečnosti a svépomoc členů je (až na sebeobranu proti agresi) vyloučena, pak ústava tohoto společenství musí stanovit postup zajišt'ující efektivní ochranu práv členů proti všem možným porušením. Podle Kelsena však Charta zdaleka nenaplnila tyto požadavky. Nezakládá totiž obligatorní rozhodování sporů, které mohou vzniknout mezi členy. Členské státy nejsou povinné předložit své spory Mezinárodnímu soudnímu dvoru nebo jiným mezinárodním tribunálům. ${ }^{31}$

Kelsen ovšem vidí problémy nejen v textu Charty, ale i v její aplikaci. Upozorňuje, že byt' je výkon sebeobrany podle čl. 51 dovolený, pouze než Rada bezpečnosti přijme nezbytná opatření k obnovení míru, resp. než se uvede do chodu systém kolektivní bezpečnosti. Není však vyloučeno, že systém kolektivní bezpečnosti zůstane zablokován, protože Rada bezpečnosti není schopna plnit své funkce. To může být nejen proto, že její rozhodování o přijetí opatření $\mathrm{k}$ obnovení míru je podřízeno právu veta stálých členů, ale také proto, že nebylo možné uzavř́ít zvláštní dohody o poskytnutí vojenských kontingentů Radě bezpečnosti. Pokud má kolektivní bezpečnost malou naději na fungování, pak nezbyde nic jiného než kolektivní sebeobrana. To však znamená válku, ve které se pravděpodobně obě strany budou dovolávat svého práva na sebeobranu, protože tu není žádný objektivní orgán (kromě paralyzované Rady bezpečnosti), aby rozhodl, kdo je agresorem. Může se ukázat nezbytným nahradit kolektivní bezpečnost podle Charty kolektivní sebeobranou, ale takové nahrazení, uzavírá Kelsen, by bylo krachem politického a právního systému OSN. ${ }^{32}$

28 Ibid., s. 704-785.

29 Ibid., s. 788.

30 Viz KELSEN, H.: The Law of the United Nations. Op. cit., s. 276-277.

31 KELSEN, H.: Collective Security and Collective Self-Defense. Op. cit., s. 789.

32 Ibid., s. 795-796. 
Jak je vidět, Kelsen občas používá termínů ústavy a konstitucionalismu v oblasti mezinárodního práva, ale systém Charty OSN patrně ještě nepovažuje za adekvátní ústavní model. Na rozdíl od Paktu Společnosti národů sice Charta OSN zavádí centralizaci použití síly, ale při zablokování Rady bezpečnosti a neexistenci obligatorního rozhodování sporů MSD se skrze použití sebeobrany situace vrací k předchozímu stavu obecného mezinárodního práva založeného na svépomoci.

\section{MEZINÁRODNĚPRÁVNÍ KONSTITUCIONALISMUS}

Jedním z moderních směrů nauky mezinárodního práva je mezinárodněprávní konstitucionalismus. ${ }^{33}$ Možná by spíše než „,moderních“ bylo třeba říci „,módních" směrů současné nauky mezinárodního práva. Tím však rozhodně nemá být a priori zpochybňována vědecká povaha a závažnost prací, které se zabývají koncepty mezinárodní ústavy a/nebo konstitucionalizace mezinárodního práva.

Určitým problémem je, že dosud neexistuje jednotná teorie mezinárodněprávního konstitucionalismu. Různí autoři zkoumají či postulují, jak vypadá nebo by mohla vypadat mezinárodní ústava, resp. jaké znaky naplňují konstitucionalizaci mezinárodního práva. Jak se píše v úvodu k citované knize o Konstitucionalizaci mezinárodního práva, cílem je vidět, jak by mohl vypadat ústavní mezinárodněprávní rád. ${ }^{34}$ Tento př́stup, zvolený citovanými autory, se tak staví někam mezi striktně normativní a striktně deskriptivní př́stupy. Autoři tak srovnávají aktuální stav mezinárodního práva s ideou ústavy, jak je chápána v konstitucionalistickém myšlení.

To však zdaleka není jediný př́stup k doktríně mezinárodní ústavy a konstitucionalismu. Jak uvádí Bardo Fassbender, lze v doktríně rozlišovat tři proudy, a to Verdrosse a jeho školu, New Haven School a doktrínu mezinárodního společenství, ${ }^{35}$ Pro účely tohoto článku můžeme vynechat politicky orientovaný př́stup k mezinárodnímu právu New Haven School, kterou reprezentují především Myres McDougal, Harold Lasswell a Michael Reisman. ${ }^{36}$

Naproti tomu zbývající dva směry velmi úzce souvisejí s naším tématem. Alfred Verdross byl jedním z nejvýznamnějších žákủ Hanse Kelsena, ale od ryzí nauky právní se postupně přikláněl $\mathrm{k}$ částečně přirozenoprávnímu pohledu na mezinárodní právo. Rozhodně jej však lze považovat za jednoho ze zakladatelů mezinárodněprávního konstitucionalismu. ${ }^{37}$ Jak vyplývá z jeho kursu v Haagské akademii mezinárodního práva,

33 Srov. zejm. KLABBERS, J. - PETERS, A. - ULFSTEIN, G.: The Constitutionalization of International Law, Oxford: OUP, 2009.

34 Viz KLABBERS, J.: Setting the scene. In KLABBERS, J. - PETERS, A. - ULFSTEIN, G.: The Constitutionalization of International Law. Op. cit., s. 4: „Our aim is to see what a constitutional international legal order could look like."

35 Viz FASSBENDER, B.: Rediscovering a Forgotten Constitution: Notes on the Place of the UN Charter in the International Legal Order. In DUNOFF, J. L. - TRACHTMAN, J. P. Ruling the World? Constitutionalism, International Law and Global Governance. Cambridge: CUP, 2009, s. 133.

36 Viz REISMAN, W. M.: The View from the New Haven School of International Law. Proceedings of the Annual Meeting (American Society of International Law), sv. 86, 1992, s. 118-125.

37 Viz VERDROSS, A.: Die Verfassung der Völkerrechtlichtsgemeinschaft. Wien - Berlin: Springer, 1926. 
považoval obecné obyčejové mezinárodní právo za skutečnou mezinárodní ústavu, nikoli pouhý postulát. ${ }^{38}$

$\mathrm{Na}$ Verdrosse pak navázali další autoři, zejména z německého a nizozemského prostředí, jako je na prvním místě Verdrossův žák a později spoluautor Bruno Simma, považující Chartu OSN za ústavu mezinárodního společenství. ${ }^{39}$ Mezi dalšími autory, kromě již dř́ív citovaných, lze zmínit také Eriku De Wet. 40

Je dokonce možné hovořit o sbližování s doktrínou mezinárodního společenství (Herman Mosler), na kterou navázal zejména Christian Tomuschat a další němečtí autoři. ${ }^{41}$

Poněkud kritičtějším způsobem přistupuje ke konceptu mezinárodní ústavy francouzská nauka mezinárodního práva. Důkladným způsobem rozebral tento koncept zejména Pierre-Marie Dupuy, který se zvláště vymezil vůči argumentu, že Charta OSN představuje ústavu mezinárodního společenství, a to jak ve studii publikované v r. 1997, ${ }^{42}$ tak i později ve svém kursu v Haagské akademii mezinárodního práva a jinde. ${ }^{43}$ Dupuy sice uznává ústavní dimenze Charty OSN, ale považuje za problematické ji jednoduše označit za ústavu, na základě zjednodušující analogie s vnitrostátními právními řády. Spatřuje hlavně problém $\mathrm{v}$ neurčitosti až vágnosti pojmu ústava, kterým se označují různé věci $\mathrm{v}$ různých právních tradicích. Proto k používání konceptu ústavy v mezinárodním právu přistupuje s opatrností. Na jisté úrovni připouští, že Charta přináší určitou jednotu do mezinárodního společenství, jakož i obecné zásady, které vytvářejí substantivní jednotu mezinárodněprávního řádu, ale na druhé straně nezajišstuje takovou formální a institucionální jednotu, aby bylo namístě jí označovat za „,ústavu“.

S touto kritikou pojmové neurčitosti uvnitř doktríny „konstitucionalizace“ mezinárodního práva souhlasí také Dupuyho žák, Oliver de Frouville. ${ }^{44}$ Zároveň se však snaží ukázat, že koncept ústavy je užitečný k porozumění a popsání mezinárodního práva. Odkazuje přitom na staršího francouzského autora Georges Scelle, který byl současníkem H. Kelsena. Scelle je známý jako představitel sociologického směru nauky

38 Viz VERDROSS, A.: Règles générales du droit international de la paix. Recueil des Cours, sv. 30, 1929, s. 354: „En effet, le droit des gens contient des règles coutumières bien établies qui forment une véritable constitution internationale obligeant toutes les autorités. La primauté du droit des gens, ou mieux de la constitution internationale, n'est donc pas un postulat, mais une réalité.“

39 SIMMA, B.: From Bilateralism to Community Interest in International Law. Recueil des Cours, sv. 250, 1994, s. 258 an.

40 DE WET, E.: The International Constitutional Order. International and Comparative Law Quarterly, Sv. 55, 2006, s. 51-76.

41 Srov. TOMUSCHAT, CH.: Obligations Arising for States without or against Their Will. Recueil des Cours, sv. 241, 1993, s. 195; FROWEIN, J.: Reactions by not directly affected States to breaches of public international law. Recueil des Cours, sv. 248, 1994, s. 345.

42 DUPUY, P.-M.: The Constitutional Dimension of the Charter of the United Nations Revisited. Max Planck Yearbook of United Nations, sv. 1, 1997, s. 1-33.

43 DUPUY, P.-M.: L'unité de l'ordre juridique international. Cours général de droit international public. Recueil des Cours, sv. 297, 2002, s. 215 an.; DUPUY, P.-M.: Ultimes remarques sur la 'constitutionalité' de la Charte des Nations Unies. In CHEMAINE, R. - PELLET, A.: La Charte des Nations Unies, Constitution mondiale? Paris: Pedone, 2006, s. 219-232.

44 FROUVILLE, O. de: On the Theory of International Constitution. In ALLAND, D. - CHATAIL, V. FROUVILlE, O. de - VIÑUALES, J. E. (eds.): Unity and Diversity of International Law. Essays in Honour of Professor Pierre-Marie Dupuy. Leiden: Martinus Nijhoff Publ., 2014, s. 78. 
mezinárodního práva, zvaného solidarismus, ale zpravidla nebýval spojován s konstitucionalismem.

Na rozdíl od dř́ve zmíněných stoupenců konstitucionalismu v mezinárodním právu, kteří spojují pojem ústavy až s formováním mezinárodního společenství, udržovaného nejen společnými zájmy, ale i společnými hodnotami, Scelle chápal ústavu jako jev, který je inherentní každému právnímu řádu, který zase přirozeně vzniká s existencí každé lidské společnosti. Jinak řečeno, ústava $\mathrm{v}$ tomto smyslu je přítomná $\mathrm{v}$ mezinárodním právu od jeho počátku. ${ }^{45}$

Jakkoliv Scelle a Kelsen vycházeli ze zcela odlišných teoretických základů, v určitém ohledu lze najít bod, který je spojuje. Když G. Scelle posuzoval vývoj ohledně zákazu vedení války, poznamenal, že vývoj mezinárodního práva povede nevyhnutelně $\mathrm{k}$ větší institucionalizaci mezinárodního řádu a může nakonec vyústit v univerzální ř́̌ši nebo světovou federaci. ${ }^{46}$ Ostatně také Kelsen již ve svém prvním kursu v Haagské akademii (1926) akceptoval přirovnání mezinárodněprávního řádu k pojmu civitas maxima. ${ }^{47}$

I když akceptujeme myšlenku, kterou O. de Frouville převzal od G. Scelle, že nějaký koncept ústavy byl v mezinárodním právu vždy přítomný, určitě bude „ústava“, jak ji prezentuje současný mezinárodněprávní konstitucionalismus, vypadat odlišně od ústavy $\mathrm{v}$ počátcích mezinárodního práva, $\mathrm{v}$ rámci Westfálského systému a ještě v době Společnosti národů. Je zřejmé, že použitelný koncept ústavy nemá nic společného s psanou a rigidní ústavou, naopak půjde o systém komplexní, otevřený a nestabilní.

Základním ústavním principem Westfálského systému je suverenita států, tedy formální rovnost svrchovaných států, výlučná teritoriální jurisdikce a nezasahování do vnitřních věcí státu. Určité základní prvky současné mezinárodní ústavy lze najít v Chartě OSN ${ }^{48}$ Patří mezi ně posun od konceptu negativního míru k pozitivnímu míru a úloha mezinárodních organizací pro zajištění podmínek pro trvalý mír. Zákaz použití síly $\mathrm{k}$ řešení sporů, který byl doplněný systémem kolektivní bezpečnosti. Vyhlášení univerzálních lidských práv. Narůstající centralizace pro zajiššění sociálních funkcí, a to jak cestou orgánů OSN, tak vytvářením specializovaných mezinárodních organizací. Úprava vztahů OSN s regionálními organizacemi (čl. 53-54). Důraz na mírové řešení sporů, zejm. judiciální řešení sporů. Zakotvení určité hierarchie norem (čl. 103), stanovením přednosti závazků podle Charty před ostatními mezinárodními dohodami.

45 Viz SCELLE, G.: Précis de droit des gens II, Droit constitutionnel international, Paris: Sirey, 1934, s. 7: „Toute collectivité intersociale, y compris la communauté universelle du Droit des Gens repose, comme les collectivités mieux intégrées et notamment les collectivités étatiques, sur un ensemble de règles constitutives essentielles à leur existence, à leur durée, à leur progrès. Là même où ces collectivités paraissent avoir l'organisation la plus rudimentaire, où les normes fondamentales semblent les plus indécises et où les institutions paraissent inexistantes, une constitution au sens large, mais au sens juridique, ne s'en révèle pas moins."

46 Viz SCELLE, G.: Quelques reflexions sur l'abolition de la compétence de guerre. Revue Générale de Droit International Public, sv. 58, 1954, s. 22.

47 Viz KELSEN, H.: Les rapports de système entre le droit interne et le droit international public. Op. cit., s. 319: „L'ordre juridique international est en effet, selon un qualificatif qu'on lui a autrefois occasionnellement appliqué, une civitas maxima; il l'est dès aujourd'hui."

48 Srov. CRAWFORD, J.: The Charter of the United Nations as a Constitution. In CRAWFORD, J.: International Law as an Open Systém. London: Cameron May, 2002, s. 123. 
Některé další nejsou sice obsažené přímo v Chartě, ale vyvinuly se souběžně nebo následně jako jejich doplněk. Nepochybně sem patří další typ hierarchie norem spojený $\mathrm{s}$ jus cogens $\mathrm{v}$ mezinárodním právu. $\mathrm{V}$ mezinárodním právu se rovněž rozvinula a zčásti kodifikovala pravidla odpovědnosti států, ale také mezinárodních organizací, jakož i individuální trestní odpovědnost $\mathrm{v}$ př́ípadě nejzávažnějších zločinů podle mezinárodního práva. V posledních desetiletích se pak navíc dostávají do zájmu mezinárodního práva vedle již uznávaných subjektů (státy, mezivládní organizace a jednotlivci) také nestátní aktéŕi, ${ }^{49}$ objevují se koncepty přenesené z vnitrostátního práva, jako právní stát (Rule of law). Někteří autoři dokonce zdůrazňují demokratické principy. ${ }^{50}$

To však neznamená, že ústavní principy staršího mezinárodního práva byly jednoduše opuštěné ve prospěch nových. Naopak, princip suverenity je stále př́tomným (a pro řadu států dokonce nejdůležitějším) principem. Spíše tak dochází k jeho upřesňování a částečné obsahové proměně, a to se zdůrazněním toho, že nejde o absolutní a faktickou moc, ale spíše o právní status, který vedle oprávnění znamená i odpovědnost či povinnosti státu ve vztahu ke svým obyvatelům (jako koncept Odpovědnosti za ochranu, R2P).

Kromě toho konstitucionalistický př́stup k mezinárodnímu právu musí čelit také značným výzvám, které vycházejí z fragmentace tohoto systému. V současné době je mezinárodní právo fragmentované jak na geografickém základě (nárůst počtu a síly regionálních subsystémů mezinárodního práva), tak na sektorovém principu. ${ }^{51} \mathrm{~V}$ prvém př́padě jde o rozpor mezi regionalismem a univerzalismem, $\mathrm{v}$ druhém př́ípadě o projev zmnožení produkce a specializace norem mezinárodního práva, vzniku nových odvětví a autonomních režimů (self-contained regimes).

V určitém smyslu může být konstitucionalismus vnímán také jako doktrinární odpověd' na rizika spojená s fragmentací mezinárodního práva. Z praktického hlediska se však zdá, že spíše než „ústavni““ teorie může k systémové integraci mezinárodního práva prrispět výklad a aplikace práva mezinárodními soudy a tribunály. Takový pohled není cizí ani Kelsenovi, který vysoce hodnotil roli mezinárodních soudů a kritizoval státy za neochotu jim předložit $\mathrm{k}$ rozhodnutí všechny jejich spory. ${ }^{52}$ Nelze však zapomínat na to, že neexistuje jednotný mezinárodní soudní systém, jednotlivé mezinárodní soudní orgány jsou samostatné, založené na speciálních smlouvách či statutech.

\section{ODLIŠNOSTI KELSENOVY TEORIE A MEZINÁRODNĚPRÁVNÍHO KONSTITUCIONALISMU}

Na první pohled by se mohlo zdát, že současný mezinárodněprávní konstitucionalismus navazuje na dílo H. Kelsena, i když nebývá zpravidla citováno moderními autory hlásícími se ke konstitucionalistickému proudu. Možná někteří pova-

\footnotetext{
49 Srov. DUPUY, P.-M.: Sur les rapports entre sujets et 'acteurs' en droit international contemporain. In VOHRAH, L. C. et al. (eds.): Man's Inhumanity to Man. Essays on International Law in honour of Antonio Cassese. The Hague - New York: Kluwer, 2003, s. 261.

50 Viz PETERS, A. Dual Democracy. In KLABBERS, J. - PETERS, A. - ULFSTEIN, G.: Op. cit., s. 263.

51 Viz FROUVILLE, O. de: Op. cit., s. 98-99.

52 Viz KELSEN, H.: Law and Peace in International Relations. Op. cit., s. 167.
} 
žují Kelsena za starého a překonaného autora. Možná je to ale proto, že některé z jeho myšlenek považují v dnešní době za skoro samozřejmé. Domnívám se však, že ani dnes nelze např́klad monistickou teorii s primátem mezinárodního práva brát za úplně samozřejmé řešení vztahu mezinárodního a vnitrostátního práva, když stále mnoho států vychází z dualistického nebo smíšeného pojetí. Tím méně to platí pro další aspekty Kelsenovy teorie mezinárodního práva. Je evidentní, že jeho pojetí státu a suverenity jakožto právem upraveného a chráněného statusu (nikoli faktického, mocensky daného statusu) je rozhodně mnohem bližší dnešním mezinárodněprávním konstitucionalistům než (např́ílad) pojetí C. Schmitta. Je tak určitým paradoxem, že v současné literatuře bývá tento autor citován častěji než Kelsen.

Rovněž Kelsenovo pojetí mezinárodního práva jako uspořádaného právního řádu je něčím, v čem může být blízký dnešnímu mezinárodněprávnímu konstitucionalismu. V určitém smyslu je konstitucionalismus odpovědí na rizika fragmentace mezinárodního práva a jeho nekontrolované de-formalizaci. Spojuje je také důraz na legalitu.

$\mathrm{Na}$ druhé straně nelze přehlédnout určité rozdíly mezi Kelsenem a dnešním mezinárodněprávním konstitucionalismem. Pro Kelsena je charakteristický důraz na odpovědnost a sankce $\mathrm{v}$ mezinárodním právu jako zcela klíčové prvky nutné pro jeho fungování jako právního řádu. Současný konstitucionalismus sice také klade důraz na odpovědnost, ale chybí její jednotné chápání. Vedle klasické odpovědnosti státu (State responsibility) za protiprávní chování, což je dnes kodifikovaný institut obyčejového mezinárodního práva, se operuje také s odpovědností mezinárodních organizací, jednotlivců a dalších, nestátních aktérů, včetně korporací, a to odpovědností v širším smyslu (accountability). Důraz na sankce je také poněkud oslaben, a to nejen důrazem na řešení sporů (zejm. mezinárodní soudnictví), ale také na další mechanismy určené ke kontrole dodržování závazků (compliance control).

Odlišnosti lze nalézt i v př́stupu Kelsena a dnešních konstitucionalistů $\mathrm{k}$ institutu uznání státu. Pro Kelsena je zásadní rozlišení uznání jako politického aktu a právního aktu. ${ }^{53}$ Zatímco politický akt znamená ochotu uznávajícího státu navázat normální politické a jiné vztahy s uznávaným, jde o volné uvážení státu, které může být spojené s podmínkami nebo bezpodmínečné, právní uznání je jednostranný akt, který potvrzuje, že uznávaná jednotka splňuje objektivní podmínky, aby byla státem ve smyslu mezinárodního práva, tj. subjektem práv a povinností stanovených mezinárodním právem. ${ }^{54}$

Naproti tomu u dnešních konstitucionalistů, kteří spojují právo na sebeurčení a uznání s principy demokracie a lidských práv, se zdá, řečeno z kelsenovského pohledu, že dochází právě $\mathrm{k}$ záměně politického a právního rozměru uznání státu. Přitom prosazení deklaratorního a bezpodmínečného uznání státu bylo významným výdobytkem moderního mezinárodního práva, dosaženým poprvé v Montevidejské úmluvě o právech a povinnostech států (1933) ${ }^{55}$ a poté rozšířeným univerzálně. Znamenalo to definitivní porážku konceptu standardů civilizace, považovaných ve starším mezinárodním právu

\footnotetext{
53 Viz KELSEN, H.: Recognition in International Law. Theoretical Observentions. The American Journal of International Law, sv. 35, č. 4/1941, s. 605.

54 Ibid., s. 607-608.

55 Viz The International Conference of American States, First Supplement, 1933-1940, s. 121.
} 
za podmínku pro přijetí do rodiny „civilizovaných národů“ (rozuměno států). ${ }^{56} \mathrm{Na}$ tuto skutečnost není dobré zapomínat. Zdá se totiž, že často bona fide vnášením kritérií lidských práv a demokratických principů dochází $\mathrm{k}$ návratu něčeho velmi podobného „standardům civilizace“ $\mathrm{z}$ tradičního mezinárodního práva.

To ostatně souvisí s ještě obecnějším rozdílem mezi Kelsenem a dnešními mezinárodněprávními konstitucionalisty. I když Kelsen byl svými politickými názory levicově orientovaný liberál, svou teorii budoval jako ryzí nauku právní, důsledně oproštěnou od ideologických a politických vlivů. Naproti tomu soudobý konstitucionalismus není rozhodně hodnotově neutrální, naopak je založen na důrazu na lidská práva a demokratické principy. Jinak řečeno, neomezuje se na formální legalitu, ale jde mu také o efektivitu a legitimitu mezinárodního práva jako ústavního řádu.

Možný spor mezi Kelsenem a dnešními konstitucionalisty by se netýkal principů legality a efektivity, které by chápal jako pririrozené podmínky pro fungování právního řádu, ale právě legitimity. Jak známo, Kelsen odmítal přirozené právo, vědecké právní myšlení musí spočívat na normách pozitivního práva, bez spoléhání se na filozofické úvahy a bez vnášení politických a sociálních hodnot. ${ }^{57}$

Stejně tak by pro Kelsena byly asi těžko přijatelné koncepce soft law, nebo role nestátních aktérů, nebo dokonce právní pluralismus uznávající více zdrojů tvorby práva.

\section{ZÁVĚR}

Na konci tohoto zamyšlení budiž autorovi dovoleno, aby se pokusil odpovědět na otázku (možná poněkud spekulativní), co by dnes asi Kelsen řekl k mezinárodněprávnímu konstitucionalismu. Pravděpodobně by zaznamenal a ocenil rozvoj mezinárodního práva, včetně nárůstu role mezinárodních institucí a mezinárodního soudnictví. Asi by s uspokojením zaregistroval, že praxe mnoha států se přiklonila $\mathrm{k}$ monismu s předností mezinárodního práva. Současně by ale musel konstatovat, že některé jeho postřehy a obavy, např. ohledně fungování systému kolektivní bezpečnosti a reziduální svépomoci států, platí i po 70 letech. Patrně by připustil, že se vytvárí něco jako mezinárodní ústava, ale ani dnes by nepovažoval tento proces za dokončený.

Je velmi pravděpodobné, že Kelsen by měl značné problémy s právem EU, jakkoliv by mu byla blízká centralizace a rozdělení kompetencí mezi instituce EU a obligatorní jurisdikce Soudního dvora, nemluvě ani o přednosti práva EU před vnitrostátním právem. Zdrojem problémů by ale asi mohla být snaha EU sebeprezentovat tento dílčí právní řád jako zcela autonomní, oddělený od (obecného) mezinárodního práva.

Co se týče teorií konstitucionalismu v mezinárodním právu, domnívám se, že Kelsen by se k nim asi vymezil spíše kriticky. Patrně by mu vadila jak značná vágnost a roztříštěnost těchto teorií, tak vnášení politických a hodnotových kritérií do mezinárodněprávního řádu. Lze si dokonce představit, že by některé z těchto směru označil za přirozenoprávní.

56 Blíže srov. BECKER LORCA, A.: Mestizzo International Law. A Global Intellectual History 1842-1933. New York: Cambridge University Press, 2015.

57 Srov. RIGAUX, F.: Hans Kelsen... Op. cit., s. 340. 
Nicméně záleží na úhlu pohledu. Někteří stoupenci konstitucionalismu v mezinárodním právu si sami kriticky uvědomují úskalí tohoto směru, že totiž konstitucionalistická interpretace mezinárodního práva by mohla nebezpečně svádět k nadměrným očekáváním. Takováto rekonstrukce reality by mohla falešně vytvářet iluzi legitimního globálního vládnutí. Podle této sebekritické reflexe si však mezinárodní a ústavní právníci uvědomují, že „konstitucionalismus“ "není hotová odpověd”, ale určitá perspektiva, která by mohla pomoci při kladení správných otázek rovnosti, spravedlnosti a efektivnosti. ${ }^{58}$

$\mathrm{Z}$ tohoto pohledu lze uzavř́it, že přes určité odlišnosti není mezi učením H. Kelsena a mezinárodněprávního konstitucionalismu nepřekonatelná propast. Pokud budeme oboje chápat nikoli jako uzavřený model, ale spíše jako určité metody určené k výkladu existujícího, platného mezinárodního práva, pak si lze z nich vybrat poučení.

Z Kelsenova učení zůstává inspirující jeho logický př́stup k právnímu rrádu, včetně mezinárodního práva, který vnímá jako uspořádaný celek. Důležité je i připomenutí, že právní normy nevznikají př́mo ze společenské reality, ale na základě určitého normotvorného procesu, ve kterém mají rozhodující roli státy. Proto je třeba odlišovat pohled (a metody) právní vědy a politologie, resp. mezinárodních vztahů. Na druhé straně nám mezinárodněprávní konstitucionalismus připomíná vázanost všech subjektů, včetně států, normami mezinárodního práva, vzrůstající roli mezinárodních organizací a soudů, jakož i to, že mezinárodní právo není hodnotově neutrální, ale slouží k ochraně míru, spravedlnosti a lidských práv.

prof. JUDr. Pavel Šturma, DrSc.

Univerzita Karlova, Právnická fakulta

sturma@prf.cuni.cz

58 Viz PETERS, A.: Conclusion. In KLABBERS, J. - PETERS, A. - ULFSTEIN, G.: Op. cit., s. 344. 